\title{
Effect of Natural and Forced Convection Solar Dryers in Retention of Proximate Nutrients in Tomato
}

\author{
Kusum Sharma ${ }^{1}$ and Nikita Wadhawan ${ }^{2}$ \\ ${ }^{1}$ College of Home Science, Udaipur, India \\ ${ }^{2}$ Department of Food Science and Technology, CDFST, Udaipur, India \\ *Corresponding author
}

\section{A B S T R A C T}

\section{Keywords}

Solar drying,

Natural convection,

Forced convection,

Tomato, Colour,

Benefit cost ratio,

Chemical

(proximate)

composition

Article Info

Accepted:

08 June 2018

Available Online:

10 July 2018
Fruit and vegetables $(\mathrm{F} \& \mathrm{~V})$ are living tissues and highly perishable products needing optimal post-harvest technologies in order to maintain their storage stability and extend shelf life. The experiment was conducted in the winter months. Dried tomato slices ground to obtain powder. Dried powder was analyzed for its proximate composition that is moisture, crude fat, crude protein, crude fiber, ash, carbohydrates and energy. Nutritional characteristics of the dried powders were analyzed for proximate composition along with fresh fruit on dry weight basis. Results showed that fat, protein, ash content was found more in forced convection solar dried tomato. Color retention in forced solar dried powder found better when compared to natural convection solar dryer. Drying was also found faster in forced convection solar dryer. The benefit cost ratio in natural convection solar dryer for tomato was found to be 2.11 with a payback period of 2.53 years. The benefit cost ratio in forced convection solar dryer for tomato was found to be 2.91 with a payback period of 245 days. Hence, it can be inferred that the dryer is technically as well as economically feasible.

\section{Introduction}

Tomato (Solanum lycopersicum), a nutritious fruit commonly used as a vegetable, is another wonderful gift of Mayans. The humble vegetable has grabbed the attention of millions of health seekers for its incredible phytochemical properties than that in an apple. Interestingly, it has more health-benefiting properties than that in a Tomatoes are one of the low-calorie vegetables. They are also very low in any fat contents and have zero cholesterol levels. Nonetheless, they are excellent sources of antioxidants, dietary fiber, minerals, and vitamins. Because of their allround qualities, dieticians and nutritionists often recommend them to be included in cholesterol controlling and weight reduction programs. The antioxidants present in tomatoes are scientifically found to be protective of cancers, including colon, prostate, breast, endometrial, lung, and pancreatic tumors. Drying is a process to remove water from a substance. It is one of the 
most frequently and widely used operating process in daily life and is undesirably an energy intensive operation.

Open sun drying under hostile climate conditions leads to severe losses in the quantity and quality of the dried products whereas mechanical drying is an energy consuming operation in the post- harvesting. Therefore, a dryer working on solar energy may be considered as a feasible option in this context. Also there is considerable shift from fresh to more and more processed foods with significant changes taking place in the country and the rapid integration of Indian economy with global system. Since long large numbers of studies have been conducted on varied techniques of drying, still there is no clear-cut evidence as to which method of drying is best in terms of nutrient retention. In this paper attempt has been made to evaluate the performance of the two dryers (NC and FC) in retention of proximate nutrients in edible portions of Tomato.

\section{Natural convection dryer}

This solar dryer was designed and developed by the Punjab Agricultural University (PAU), Ludhiana, India under the auspices of the All India Coordinated Research Project (AICRP) on Renewable Energy Sources. The system was commissioned at the College of Technology and Engineering, Udaipur (27' $42^{\circ} \mathrm{N}, \quad 75^{\prime} 33^{\circ} \mathrm{E}$ ) for drying agricultural produces as illustrated in Figure 1. This dryer consists of two parts, solar collector and drying cabinet.

The solar collector has a metallic type frame structure covered by glass from the top and is insulated from bottom to reduce the heat losses. The dryer works on natural draft mode, and in order to maintain such draft a chimney is provided on the top of the dryer.
Natural convection solar dryer (PAUmodel) (see online version for colours)

\section{Technical specification of natural convection solar dryer}

Location Udaipur $\left(27^{\prime} \quad 42^{\circ} \mathrm{N}, \quad 75^{\prime} \quad 33^{\circ} \mathrm{E}\right)$

Collector area $2.391 \mathrm{~m} 2$

Drying cabinet area (outer) $0.781 \mathrm{~m} 2$

Drying cabinet area (outer) $0.448 \mathrm{~m} 2$

Number of chimney 1

Height of chimney $0.10 \mathrm{~m}$

Area of chimney opening $0.0625 \mathrm{~m} 2$

Collector glazing material Glass

\section{Forced convection dryer}

The solar powered forced convection dryer used for experimental investigation was designed and developed by Society for Energy, Environment and Developed (SEED), Hyderabad. The dryer is developed in such way that it has minimal thermal losses due to the direct penetration of solar radiation into the cabinet through the glass window. Solar Photo Voltaic (SPV) fan is used for forced air circulation. Provision of trolley system is given for loading and unloading of trays containing material to be dried (Figure 2).

\section{Instrumentation and measurements}

The experiment was conducted in the winter months. The global solar radiation incident on a horizontal surface was measured by Solar Pyranometer (Modle: SP Lite2 type; Make: Kipp and Zonen, Netherlands). Exit air velocity at the chimney outlet was measured using hot wire anemometer (Model No. LM4204; Make: Taiwan). Calibrated PT 100 thermocouples connected to a multi-channel temperature scanner (ADI-Vadodara, Gujarat, India) was used to measure the drying air temperatures. The ambient temperature, moisture content (wb) of product during drying was also measured. The moisture 
content of products was measured at the initial and at final stage after complete drying using moisture meter.

\section{Performance evaluation and cost effectiveness}

The performance evaluation of the natural convection (NC) and forced convection (FC) solar dryer was evaluated during no load and full load testing. Time, relative humidity and temperature inside and outside the driers were measured at equal time interval using Electronic Data Logger (Emcon).

\section{No load testing}

No load testing includes maximum stagnation temperature measurement inside the solar natural convection and forced convection dryers at different points during sun shine hours. In this context temperature at collector outlet, dryer inlet and dryer outlet were measured and other meteorological observations like ambient temperature, solar intensity and relative humidity were also recorded.

In order to test the efficiency of the dryers and judge its suitability for drying agricultural and horticultural products, no load testing was performed. This test was carried on consecutive days during month of February.

\section{Full load testing}

The full load testing was performed to obtain efficiency of dryer for drying various fruits and vegetables. The steps adopted for full load testing are described in subsequent headings.

\section{Cost effectiveness of the drier}

Different cost indicators were used for cost analysis of solar drying system under the study. The following parameters were considered to assess the cost of the dryer.

1. The life of solar dryer assumed as 10 years

2 . The discount rate is assumed to be $10 \%$

3 . The annual repair and maintenance cost is $3 \%$ of the cost.

4. Cost of tomato Rs. $10 / \mathrm{kg}$ respectively.

5. The drier can be operated for 250 days in a year.

6. Cost of labour is 2000 Rs. in a year

a. Net annual saving: The net present worth or annual saving can be computed by subtracting the total discounted present worth of the cost stream for that of the benefit stream.

$\mathrm{NPW}=\mathrm{t}=\mathrm{nBt}-\mathrm{Ct}$
$(1+\mathrm{i})^{\mathrm{t}}$

Where, $\mathrm{Ct}=$ cost in each year

$\mathrm{Bt}=$ benefit in each year

$$
\begin{aligned}
& \mathrm{t}=1,2,3 \ldots \ldots \ldots \mathrm{n} \\
& \mathrm{i}=\text { Discount rate }
\end{aligned}
$$

b. Benefit cost ratio: This is the ratio obtained when the present worth of the benefit stream is divided by the present worth of the cost stream. The mathematical benefit-cost ratio can be expressed as:

$\mathrm{t}=\mathrm{n}$

$\sum \mathrm{Bt}$

Benifit Cost Ratio $=\mathrm{t}=\mathrm{i}$

\section{$\sum \mathrm{Ct}$}

$\mathrm{t}=\mathrm{n}$

$\mathrm{t}=\mathrm{i}$

Where, $\mathrm{Ct}=$ Cost in each year

$\mathrm{Bt}=$ Benefit in each year

$$
\begin{aligned}
& \mathrm{t}=1,2,3 \ldots \ldots . . \mathrm{n} \\
& \mathrm{i}=\text { Discount rate }
\end{aligned}
$$

c. Payback period: The payback period is the length of time from the beginning of the project until the net value of the incremental production stream reaches the total amount of the capital investment. It shows the length of 
time between cumulative net cash outflow recovered in the form of yearly net cash inflow.

\section{Physical characteristics}

Color: The obtained powders from both the drying methods was differently analyzed for color retention using Hunter Lab Colorimeter (Dou et al., 2003). From the dried samples 10 gram of sample was put into the petri -plate of the colorimeter and readings were recorded.

\section{Principle:}

Three elements are necessary to see color: a light source, an object and an observer. A light source emits light that appears white, but when diffracted by a prism, represents all wavelengths in the visible light spectrum (400 - $700 \mathrm{~nm}$ ). Colorimeters use illuminants, which are plots of relative energy versus wavelengths, to represent different light source under standardized and quantifiable conditions.

Three-dimensional scale, such as CIE L*a*b*, have been developed to objectively quantify color values. This scale defines color as follows:

$\mathrm{L}^{*}$ (lightness) axis: black to white (0-100)

$\mathrm{a}^{*}$ (red-green) axis: positive values are red; negative values are green; 0 is neutral

$\mathrm{b}$ *(yellow-blue) axis; positive values are yellow; negative values are blue; 0 is neutral

b. Particle size: The obtained dried shreds of sliced tomato were ground in an electric mixer (Sumit) and sieved to obtain the instant mix of BSS 100 mesh size.

\section{Proximate analysis}

The fruit in the fresh and dried forms was analyzed for proximate composition. Proximate composition such as moisture, crude fat, crude protein, crude fibre, ash, carbohydrates and energy were determined using standard procedures and formulas of NIN and Jain and Mogra in the laboratory of Department of Foods and Nutrition, College of Home Science, Udaipur (Fig. 3-9).

\section{Statistical analysis}

The results were presented as means and standard deviations computed. Analysis of variance (ANOVA) was used to determine whether significant differences existed ( $\mathrm{p}<$ 0.05 ) in nutrient content between fresh, natural and forced convection solar dried Tomato powder.

\section{Results and Discussion}

\section{Performance evaluation of natural versus forced convection solar dryers}

\section{No load testing}

The dryer was tested for no load and maximum temperature was found to be $64.8^{\circ} \mathrm{C}$ and $77.4^{\circ} \mathrm{C}$ in natural and forced convection solar dryers respectively. The performance of forced and natural solar convection dryer under no load condition was carried out in order to find out maximum temperature attained inside the dryers.

\section{Natural convection dryer}

It was observed that the solar intensity increased up to 13:00 hour and then decreased. Similarly, the ambient temperature increased with the daytime and slightly decreased in late hours. Maximum temperature obtained inside the dryer was $64.8^{\circ} \mathrm{C}$ at 13:00 hour corresponding to ambient temperature of $37.3^{\circ} \mathrm{C}$ and solar radiation of $995.06 \mathrm{~W} / \mathrm{m}^{2}$ in the month of February. The inside temperature was $25-30^{\circ} \mathrm{C}$ above ambient temperature during day time. The average collector 
efficiency during test was 52 per cent.

\section{Forced convection dryer}

It was observed that the solar intensity increased up to 13:00 hour and then decreased. Similarly, the ambient temperature increased with the daytime and slightly decreased in late hours. Maximum temperature obtained inside the dryer was $77.4^{\circ} \mathrm{C}$ at $13: 00$ hour corresponding to ambient temperature of $27.3 \mathrm{oC}$ and solar radiation of $977.5 \mathrm{~W} / \mathrm{m} 2$ in the month of February. The inside temperature was $35-40 \mathrm{oC}$ above ambient temperature during daytime. The average collector efficiency during test was 52 per cent. While in no load testing, the results showed that temperature attained inside forced convection dryer was higher as compared to the natural convection dryer (Sabah and Abdul, 2013).

\section{Full load testing}

In order to check the efficiency of dryers full load testing was conducted and results are presented in subsequent headings.

\section{A.Initial moisture content}

It was determined before drying was started. The initial moisture content of tomato was 81.60 and 80.49 per cent respectively (Table: $1)$.

\section{Preparation of the products for drying}

Total of $10 \mathrm{~kg}$ tomatoes were procured, cleaned and shredded/ sliced. The initial weight of the products was measured before placing them in the dryer. Equal quantities of $5000 \mathrm{~g}$ of sliced, tomatoes were kept in both the dryers for drying (Table 1).

\section{Drying of products}

Observations during drying of products include time for complete drying and final moisture content of the product. The final moisture of the products was measured through moisture meter (Sartorius).

Table 2 indicates that it took 60 hours for complete drying of tomato in NC solar drier whereas it took only 40 hours for complete drying of tomato in FC solar drier. This was due to the fact that in NC drier the drying was only due to natural air circulation and only during day time, whereas in FC dryer, the drying was continuous and occurred during night also due to the presence of exhaust fans. This difference in drying time was also observed because FC solar drier was working at $40^{\circ}$ to $85^{\circ} \mathrm{C}$ temperature during drying time, whereas NC solar drier was working at $25^{\circ}$ to $65^{\circ} \mathrm{C}$ when ambient temperature was $35.3^{\circ} \mathrm{C}$.

Results indicate that initial moisture content of tomato 84.49 per cent was reduced to 5.02 and 5.42 per cent, respectively in natural and forced convection solar drier after, complete drying. Final weight of tomato was $110 \mathrm{gm}$ and $240 \mathrm{gm}$ after complete drying by natural and forced convection solar dryer respectively (Table 2). Hence, the results reveal that there was better retention of weight in forced convection drier for both the selected products. The recovery in terms of weight was more for tomato in FC as compared to $\mathrm{NC}$ solar dryer.

Similarly, Ajeetkumar et al., (2013) reported that a greenhouse drier was designed fabricated and its performance was tested in the force convection mode of heat transfer. A thermal model of the system was developed in the forced convection greenhouse drier and in the natural convection open sun-drying mode. Experiments were conducted in the premises of SHIATS-DU Allahabad at latitude of $25^{\circ} \mathrm{N}$. Measurements of solar intensity, relative humidity inside and outside the green house drier, moisture removal rate, air velocity and temperatures at different points were recorded. It was found that the average convective heat transfer coefficient for the forced convection 
greenhouse-drying mode was higher than the open sun drying.

\section{Cost effectiveness}

Natural convection solar drying for drying of tomato

The benefit cost ratio in natural convection solar dryer for tomato was found to be 2.11 with a payback period of 2.53 years. Hence, it can be inferred that the dryer is technically as well as economically feasible.

Forced convection solar dryer for drying tomato

The benefit cost ratioin forced convection solar dryer for tomato was found to be 2.91 with a payback period of 245 days. Hence, it can be inferred that the dryer is technically as well as economically feasible (Table 3 and 4).

Physical and nutritional characteristics of the dried products

\section{Physical characteristics}

\section{Color}

The dried slices of Tomato were ground to powder and their weights were $110 \mathrm{gm}$ from natural convection and $240 \mathrm{gm}$ from forced convection. The obtained powders from both the drying methods were differently analyzed for color retention using Hunter Lab colorimeter (Dou et al., 2003).

It is found that the values of physical properties for surface color in natural convection and forced convection tomato $\mathrm{L}^{*}$, $a^{*}, b^{*}$ were different from each other. Color retention in forced convection based SEED solar dryer was more as compared to natural convection solar dryer. Hence, forced convection solar dryer was found to be better in retaining the color in the dried products. Similar results were obtained when organoleptic quality test of the dried tomato samples showed that samples in the forced convection solar dryer retained their attractive red colour similar to fresh tomato indicating no mould growth and tasted more like fresh tomatoes. While samples of tomato dried under natural convection, dryers showed sign of mould growth and the colour changes to black (Abdullahi et al., 2013).

\section{Particle size}

The obtained powder was free flowing and its particle size was suitable for instant mix sieved through BCC 100 mesh size.

Moisture: The mean moisture content (Table 5 ) of natural and forced convection tomato was 5.42 and 5.02 per cent respectively. There was no significant difference in moisture content found between natural and forced convection dried samples but when compared with fresh fruit, it was found that fresh tomato contains significantly higher $(\mathrm{P}>\quad .05)$ moisture content as compared to forced and natural convection dried powder.

Similar observations were reported by Fakeye, (2009) where the moisture content was higher in the fresh vegetables than in solar and sundried vegetables, reported similar results. The high moisture content in fresh form is expected since it has been reported that vegetables in their fresh state contain $85 \%$ water.

Fat: The mean fat content of tomato dried by natural convection solar dryer was $1.24 \mathrm{~g} / 100 \mathrm{~g}$ whereas in forced convection solar dried tomato it was $1.42 \mathrm{~g} / 100 \mathrm{~g}$. No significant difference was found in fat content of both the dried products when compared with each other but significant difference was found between natural convection and fresh tomato $(\mathrm{P}>.05)$. 
Highest fat content was found in tomato dried by FC drying method.

High fat content in dried samples is attributed to the fact that moisture is evaporated. Most dried foods actually have a higher concentration of protein, fats and carbohydrates per cup than the fresh produce. Ogbonnaya and Shaba, (2009) where dried fish had higher fat content, reported similar findings.
Protein: The protein content of tomato dried by natural convection was $1.54 \mathrm{~g} / 100 \mathrm{~g}$ and in forced convection was $1.42 \mathrm{~g} / 100 \mathrm{~g}$ whereas in fresh tomato it was $1.27 \mathrm{~g} / 100 \mathrm{~g}$. There was no significant difference between the mean protein content of tomato in natural, forced and fresh form. The results indicate that protein content in the two dried samples were at par with the protein content of fresh Hassan, et al., (2007) made similar observations on the protein content of the vegetables they studied.

Table.1 Initial moisture content and weight of natural and forced convection products

\begin{tabular}{|l|l|l|l|l|}
\hline S. No. & Product & $\begin{array}{l}\text { Initial moisture content } \\
(\%)\end{array}$ & $\begin{array}{l}\text { Initial weight }(\mathrm{g}) \text { natural } \\
\text { convection }\end{array}$ & $\begin{array}{l}\text { Initial weight }(\mathrm{g}) \text { forced } \\
\text { convection }\end{array}$ \\
\hline $\mathbf{2}$ & Tomato & 80.49 & 5000 & 5000 \\
\hline
\end{tabular}

Table.2 Drying time, final moisture content and weight of the product

\begin{tabular}{|l|l|l|l|l|l|l|l|}
\hline $\begin{array}{l}\text { S. } \\
\text { No. }\end{array}$ & $\begin{array}{l}\text { Products } \\
\text { Fruit }\end{array}$ & $\begin{array}{l}\text { Drying time } \\
(\text { hrs. })\end{array}$ & $\begin{array}{l}\text { Drying time } \\
(\text { hrs. })\end{array}$ & $\begin{array}{l}\text { Final moisture } \\
\text { content }(\%)\end{array}$ & $\begin{array}{l}\text { Final moisture } \\
\text { content }(\%)\end{array}$ & $\begin{array}{l}\text { Final } \\
\text { weight }(\mathrm{g})\end{array}$ & $\begin{array}{l}\text { Final } \\
\text { weight }(\mathrm{g})\end{array}$ \\
\cline { 3 - 8 } & NC & FC & NC & FC & NC & FC \\
\hline 1 & Tomato & 60 & 40 & 5.02 & 5.42 & 110 & 240 \\
\hline
\end{tabular}

NC-Natural Convection, FC- Forced Convection

Table.3 Economic indicators for natural convection tomato drying

\begin{tabular}{|l|l|}
\hline Economic indicators for tomato & Value \\
\hline $\begin{array}{l}\text { Profitability/ income/year 300 Rs./ 5 } \\
\text { days (C) }\end{array}$ & 16,666 Rs. \\
\hline Net annual saving (D=C-B) & $\begin{array}{l}10,066 \\
\text { Rs./year }\end{array}$ \\
\hline $\begin{array}{l}\text { Benefit cost ratio = C/B B = Cost of } \\
\text { production }\end{array}$ & 2.52 \\
\hline $\begin{array}{l}\text { Payback period = A/D } \\
\text { B = Cost of production }\end{array}$ & $2.48 \quad$ Year \\
\hline
\end{tabular}


Table.4 Economic indicators for forced convection tomato drying

\begin{tabular}{|l|l|}
\hline Economic indicators for tomato & Value \\
\hline $\begin{array}{l}\text { Profitability/ income/year 300Rs./4 days } \\
\text { (C) }\end{array}$ & 15,000 Rs. \\
\hline Net annual saving (D=C-B) & $\begin{array}{l}12,325 \\
\text { Rs./year }\end{array}$ \\
\hline $\begin{array}{l}\text { Benefit cost ratio = C/B B = Cost of } \\
\text { production }\end{array}$ & 2.91 \\
\hline Payback period = A/D & $0.81 \quad$ year \\
\hline
\end{tabular}

Table.5 Mean value of Nutrient composition of tomato on dry matter basis

\begin{tabular}{|l|l|l|l|l|l|l|l|}
\hline Treatments & $\begin{array}{l}\text { Moisture( } \\
\text { percent })\end{array}$ & $\begin{array}{l}\text { Fat } \\
\mathrm{g} / 100 \mathrm{~g}\end{array}$ & $\begin{array}{l}\text { Protein } \\
\mathrm{g} / 100 \mathrm{~g}\end{array}$ & $\begin{array}{l}\text { Fibre } \\
\mathrm{g} / 100 \mathrm{~g}\end{array}$ & $\begin{array}{l}\text { Carbo. } \\
\mathrm{g} / 100 \mathrm{~g}\end{array}$ & $\begin{array}{l}\text { Energy } \\
\text { k.cal/100g }\end{array}$ & $\begin{array}{l}\text { Ash } \\
\mathrm{g} / 100 \mathrm{~g}\end{array}$ \\
\hline NCT $^{*}$ & 5.02 & 1.24 & 1.54 & 4.41 & 86.19 & 362.08 & 1.60 \\
\hline FCT $^{*}$ & 5.42 & 1.42 & 1.42 & 4.85 & 85.17 & 359.14 & 1.72 \\
\hline FT $^{*}$ & 0 & 1.58 & 1.27 & 5.49 & 90.20 & 380.1 & 1.46 \\
\hline SEM \pm & 0.11 & 0.08 & 0.14 & 0.13 & 1.22 & 1.08 & 0.07 \\
\hline $\begin{array}{l}\text { C.D. } \\
\text { P=.05 }\end{array}$ & 0.36 & 0.25 & NS & 0.40 & 3.77 & 3.34 & NS \\
\hline
\end{tabular}

*values were recorded on dry matter basis (DMB)

Fig.1 Natural convection

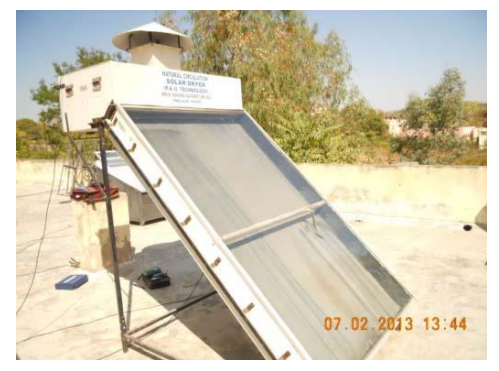

Fig.2 Forced convection

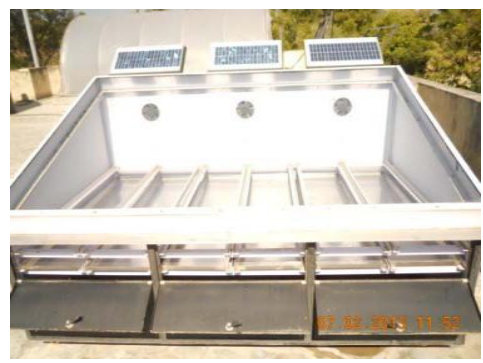

Fig.3 Full (tomato) loaded NC drier Fig.4 Full (tomato) loaded FC
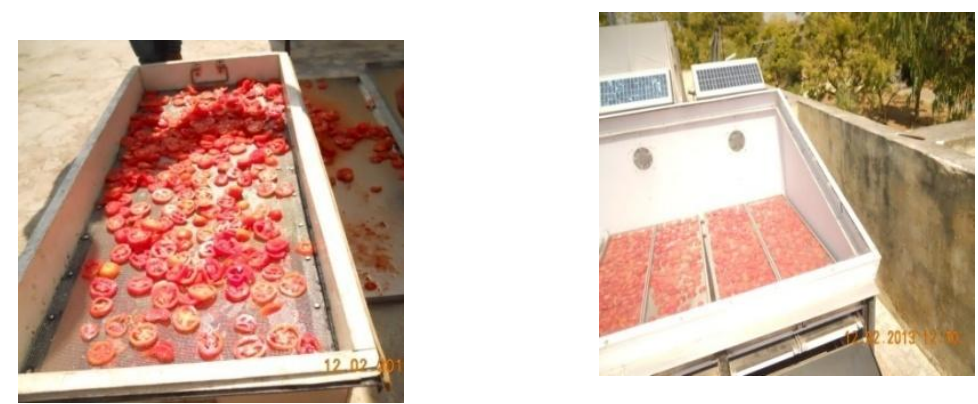
Fig.6 Variation in natural convection solar dryer during no load

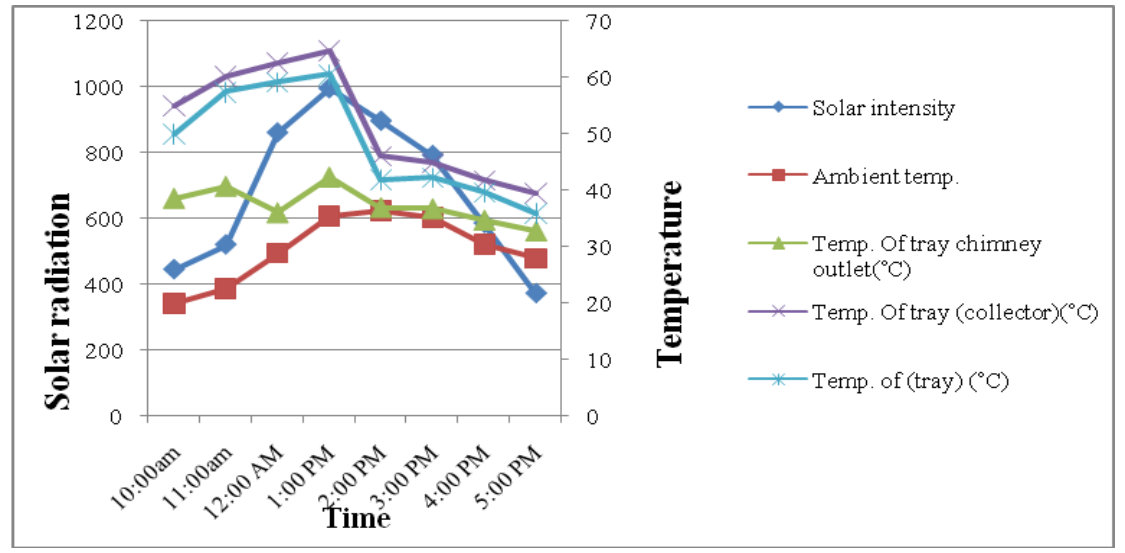

Fig.7 Variation in forced convection solar dryer during no load

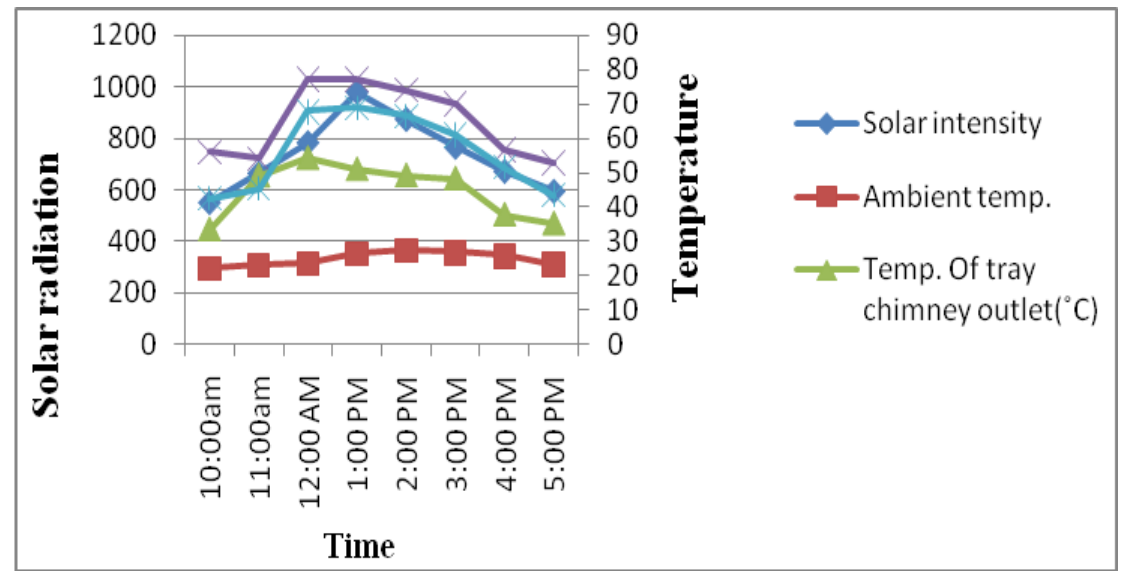

Fig.8 Hunter lab colorimeter and Samples NC, FC
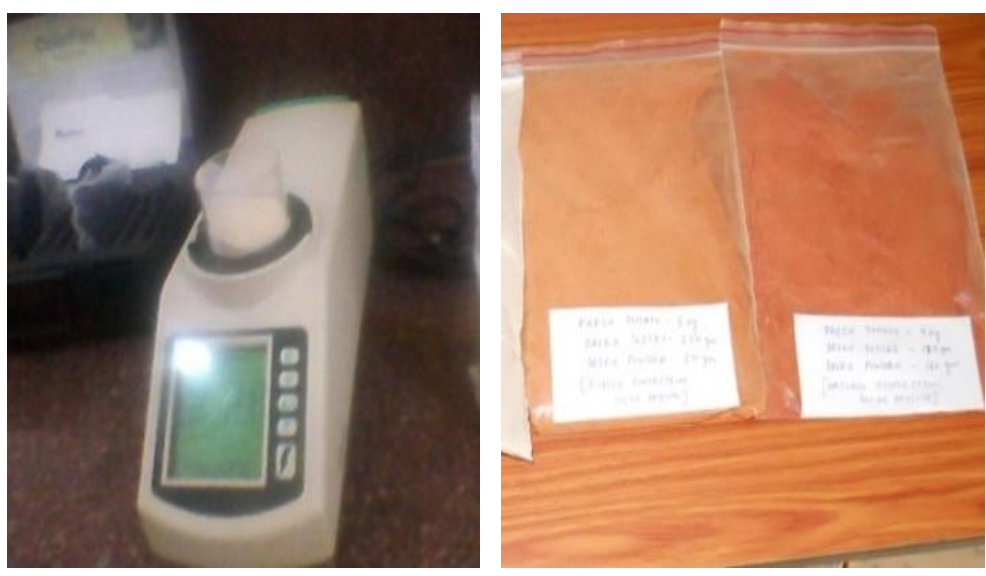
Fig.9 Color intensity value for tomato

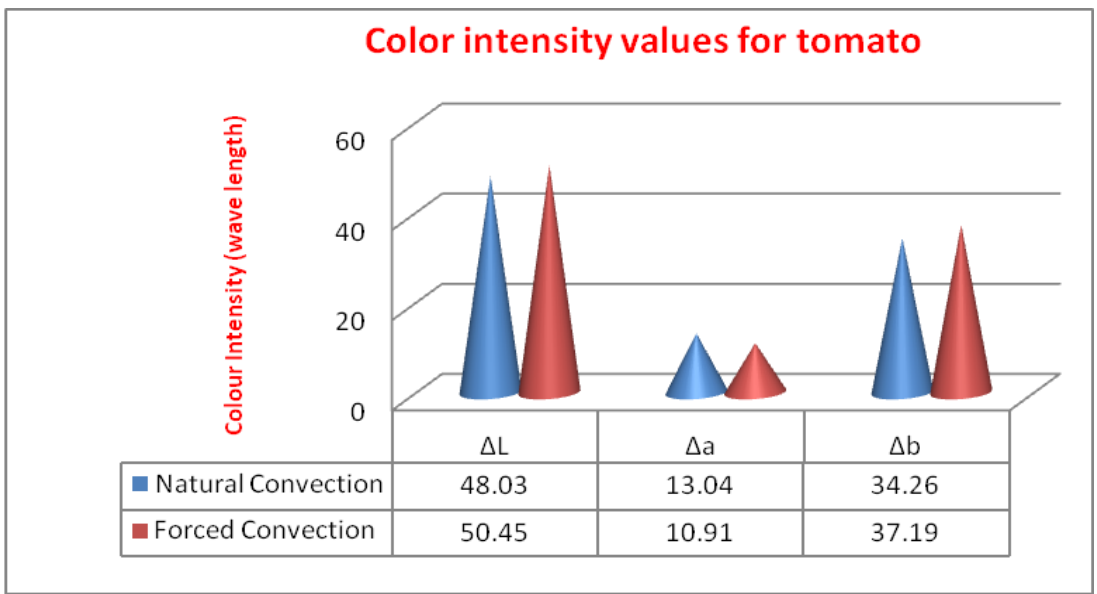

Fig.10 Proximate composition of tomato

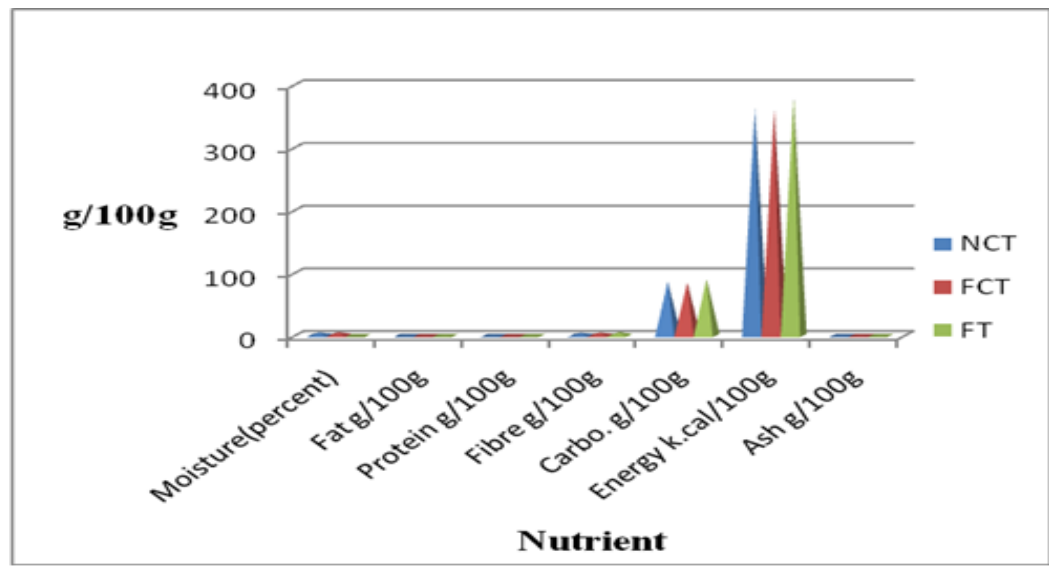

Fibre: The fibre content of tomato dried by natural convection was $4.41 \mathrm{~g} / 100 \mathrm{~g}$ where as it was $4.85 \mathrm{~g} / 100 \mathrm{~g}$ for forced convection and in fresh tomato it was $5.49 \mathrm{~g} / 100 \mathrm{~g}$. The results indicate that there is significant difference between the mean fibre content of all three natural, forced convection and fresh tomato $(\mathrm{P}$ $>$ 0.05). Results show that fresh tomato contains slightly more fibre than natural convection and forced convection tomato (Table 5).

Ifon et al., (2009) also demonstrated that crude fibre was significantly higher for solar dried vegetables. This indicates that solardried vegetables contain more fibre than the fresh vegetables. Dietary fibre in vegetables, increase bulk and reduce food transmit time in the alimentary canal and the incidence of constipation and other related diseases.

Carbohydrates: The carbohydrate content in natural convection tomato was $86.19 \mathrm{~g} / 100 \mathrm{~g}$ where as it was $85.17 / 100 \mathrm{~g}$ for forced convection tomato but in fresh tomato carbohydrates content was $90.20 \mathrm{~g} / 100 \mathrm{~g}$. The carbohydrate content of fresh tomato was calculated on dry weight basis, which was assuming that it was 0 per cent (Fig. 10).

Similar observations were reported by Agoreyo et al., (2011) that the carbohydrate 
content of all the dried samples were significantly lower $(\mathrm{P}<0.01)$ as compared to the fresh samples. Vegetables in their fresh state noted to be poor source of carbohydrates However, after drying, the carbohydrate content of vegetables will increase (on dry weight basis) Kolawole et al., (2010).

Energy: The energy in natural convection dried tomato was $362.08 \mathrm{k} . c a l / 100 \mathrm{~g}$ whereas it was $359.14 \mathrm{k.cal} / 100 \mathrm{~g}$ for (Table: 5) forced convection and in fresh tomato was $380.1 \mathrm{k}$. cal/100g. There was no significant difference $(\mathrm{P}>$.05) between the mean energy content in natural, forced and fresh tomato. This shows that energy content in two dried samples were at par with the fresh ones. Uwaegbute, (1989) reported that although fruits and vegetables are not good sources of dietary energy, and this may be because of the high water content, high crude fibre and low fat levels. In order to increase the energy value of foods, vegetables are usually supplemented with other foods such as cereals, tubers, roots and legumes.

Ash: The ash content in natural convection tomato was $1.60 \mathrm{~g} / 100 \mathrm{~g}$ where as it was $1.72 \mathrm{~g} / 100 \mathrm{~g}$ for forced convection tomato but in fresh tomato ash content was $1.46 \mathrm{~g} / 100 \mathrm{~g}$. There was no significant difference $(\mathrm{P}>.05)$ between the mean ash content in natural, forced and fresh tomato. This shows that ash in two dried samples were at par with the fresh ones (Table: 4.9). Onwuka et al., (2002) where there was the higher ash value of solar dried samples, reported similar results. Ash content indicates the mineral content of food substances. The variation in ash content might be attributed to the type of fruits used, soil variation and maturity level of fruits

In conclusion, the Proximate content of both fresh and solar dried Tomato was determined. Although losses have occurred during the process, the solar dried tomato characterizes as a valuable source of antioxidants, dietary fiber, minerals, and vitamins includes vitamin C. Concerning to tomato, the use of natural conventional solar drying led to higher nutrient loss when compared with the forced convection solar drying in respect to colour and proximate composition.

\section{References}

Abdullahi, Y., Momoh, M., Mohammad, G, M. and Musa, M. 2013. Performance Evaluation of an Adjustable and Collapsible Natural Convection Solar Food Dryer. Journal of Applied Physics, 3(3):08-18.

Agoreyo, B.O., Akpiroroh, O., Orukpe, O.A., Osaweren, O. R. and Owabor, C.N. 2011. The effect of various Drying Methods on Nutritional Composition of Musa paradisiaca, Dioscorea rotundata and Colocasia esculenta. Asian Journal of Biochemistry, 6: (6) 458-464.

Ajeet, R., Sarfaraj, A. and Shahbaj, A. 2013. An experimental Study of Forced convection Green house Drying. Journal of Food Science and Technology.14, (5) 10-16.

Dou, H. Lee, J.Y. and brown, M. G. 2003 Color flex- A New Colorimeter to Determine Orange Juice color, Proceedings of the Flora State Horticulture Society. 116: 429-432.

Fakeye, I.O. 2009. Nigerian Leafy Vegetable, Nigeria Journal of Food Science. 1: (55). 35-40.

Hassan, S.W., Umar, R.A., Maishanu, H.M., Matazu, I.K., Fruk, U.Z. and Sani, A.A. 2007. The effect of drying methods on the nutrient and non nutrients composition of leaves of Gynandropsis gynandra (capparaceae). Asian Journal of Biochemistry, 2:349-353.

http://healthyfruitandvegetablerecipes.blogspo t.in/2013/02/tomato-nutrition-facts- 
and-health.html

https://www.researchgate.net/publication/286 210750_The_stability_and_shelf_life_ of_fruit_and_vegetables [accessed Jun 08 2018].

Ifon, E.T., Bassir, O. and Latunde Dada, G.O. 2009. The nutritive value of some Nigeria leafy vegetables. Part 1, Vitamin and mineral content. Journal of Food Chemistry. 3: 267-350.

Jain, S. and Mogra, R. 2006. Analysis of Food and components, Department of Foods and Nutrition, Maharana Pratap Agriculture and Technology Udaipur (raj.), India.

Kolawale, O.M., Kayode, R.M.O., and Aina, J. 2010. Effect of solar drying on the proximate and microbial composition of Abelmoschuus escuulentus. Journal of Agriculture Science, 2: 214 - 224.

NIN, National Institute of Nutrition 2003. A Manual for Laboratory Techniques. Raghuramulu, N. Madhavan, N. K.,
Kalyansundaram, S. ICMR, Hyderabad.

Ogbonnaya, C. and Shaba 2009. Influences of drying methods on nutritional properties of Tilapia fish (Oreochromis nilotieus), World journal of agricultural sciences5 (2): $256-258$

Onwuka, G. I., Nwabara, C. C., Nwokedi, P. M., Echendu, C. A., Asumugha, U. and Igboekwe, M. U. 2002. Comparative studies of the efficacy of sun drying. Solar dryer and hot air oven in the preservation of tomatoes, okra, pepper and onion. Nigeria Food Journal. 20: 10 - 14 .

Uwaegbute, A. C. 1989. Vegetables; nutrition and utilization in food crops production, utilization and nutrition. In: Mbah, B.N., Nnanyelugo, D.O. (eds) Dotan Publications Limited, Ibadan.

\section{How to cite this article:}

Kusum Sharma and Nikita Wadhawan. 2018. Effect of Natural and Forced Convection Solar Dryers in Retention of Proximate Nutrients in Tomato. Int.J.Curr.Microbiol.App.Sci. 7(07): 1175-1186. doi: https://doi.org/10.20546/ijcmas.2018.707.142 